\title{
PENYAMAAN PERSEPSI DAN KERJASAMA DALAM PEMERIKSAAN DI BIDANG PERPAJAKAN UNTUK MENDUKUNG OPTIMALISASI PENERIMAAN NEGARA
}

\author{
Widyo Pramono \\ Jaksa Agung Muda Pengawasan \\ Email: widyopramono78@yahoo.co.id
}

\begin{abstract}
Law enforcement practices in the field of taxation has not yet had a positive correlation between the examination of taxation and the increasing of state revenues from the taxpayer. The double standards applied by the Tax Directorate in addressing abuses of legislation in the field of taxation has often occured. Therefore, it is necessary cohesion between a tax assessment and an enforcementof law on the state revenue optimization. A Such efforts can be made through: firstly, it is necessary to drawn up the characteristics of the violations and irregularities a tax regulation. The perceptions differences between law enforcement officers typically associated classification of administrative violation, crime in the area of taxation, and corruption in the field of taxation. Thus the similarity mindset, understanding and commonality of action in following up on the alleged irregularities in the field of taxation are essentially needed, There is important to do as a first step.whether through administrative action or through the enforcement of criminal law. Secondly, the integration between the principal tax debt settlement and the criminal justice process. There will be often two different things and seems "face to face" during the criminal proceedings and the principal tax debt settlement. When a taxpayer is processed through the criminal justice mechanisms and sanctions as well as criminal fines, then at the same time officers issued a tax assessment as the basis of its tax debt collection. Whereas one of the basic elements in determining the losses in state revenues is actually the result of calculation of tax liabilities and tax audit . As a result, the issuance of SKP conducted after the criminal justice process, which raises the number of "tax debts hanging ".
\end{abstract}

Keywords: Taxation, revenues, law enforcement

\begin{abstract}
Abstrak
Peraturan perundang-undangan dan berbagai praktik penegakan hukum di bidang perpajakan ternyata masih belum memiliki korelasi positif antara pemeriksaan di bidang perpajakan dengan peningkatan penerimaan negara dari wajib pajak. Standar ganda yang diterapkan Ditjen Pajak dalam menindaklanjuti pelanggaran peraturan perundang-undangan di bidang perpajakan seringkali terjadi. Oleh karena itu perlu diupayakan keterpaduan antara pemeriksaan pajak dan penegakan hukum di satu pihak dengan optimalisasi penerimaan negara. Upaya tersebut dapat dilakukan melalui pertama, diperlukan adanya pemetaan terhadap karakteristik pelanggaran dan penyimpangan di bidang perpajakan. Perbedaan persepsi antar aparat penegak hukum biasanya terkait klasifikasi pelanggaran administrasi, tindak pidana di bidang perpajakan, maupun korupsi di bidang perpajakan. Maka kesamaan pola pikir, pemahaman dan kesamaan tindakan dalam menindaklanjuti adanya dugaan penyimpangan di bidang perpajakan, apakah melalui tindakan administrasi ataukah melalui penegakan hukum pidana menjadi penting untuk dilakukan sebagai langkah awal. Kedua, adanya integrasi antara penyelesaian utang pokok pajak dengan proses peradilan pidana. Selama ini antara proses peradilan pidana dengan penyelesaian utang pokok pajak, merupakan dua hal yang terpisah dan terkadang berhadap-hadapan. Ketika seorang wajib pajak diproses melalui mekanisme peradilan pidana dan dikenakan sanksi pidana berikut denda, maka pada saat itu pula aparat Ditjen Pajak menerbitkan SKP sebagai dasar penagihan utang pajaknya. Padahal salah satu dasar dalam menentukan unsur kerugian pada pendapatan negara, sesungguhnya merupakan utang pajak hasil perhitungan dan pemeriksaan pajak. Akibatnya penerbitan SKP yang dilakukan setelah proses peradilan pidana, justru menimbulkan banyaknya "utang pajak menggantung".
\end{abstract}

Kata kunci: Perpajakan, penerimaan negara, penegakan hukum 


\section{A. Pendahuluan}

Sektor perpajakan merupakan salah satu alternatif yang dapat diandalkan dalam rangka pembiayaan pembangunan nasional, selain penerimaan negara yang berasal dari sektor migas dan non migas lainnya. Peranan strategis sektor perpajakan sebagai sumber pembiayaan pembangunan nasional, antara lain terlihat dari target yang telah dicanangkan oleh pemerintah di dalam Anggaran Pendapatan dan Belanja Negara (APBN) yang cenderung meningkat dari tahun ke tahun.

Dalam kurun waktu 5 (lima) tahun terakhir, penerimaan negara dari sektor perpajakan menunjukkan tren peningkatan yang sangat signifikan. Pada tahun 2010 penerimaan negara dari sektor perpajakan sebesar Rp. 723.307 milyar, tahun 2011 sebesar Rp. 873.874 milyar, tahun 2012 sebesar Rp. 980.500 milyar, tahun 2013 sebesar Rp. 1.148.300 milyar dan tahun 2014 sebesar Rp. 1.310.200 milyar.( Badan Pusat Statistik, www.bps.go.id, diakses pada 4 Mei 2014). Akumulasi penerimaan pajak tersebut berasal dari Pajak dalam Negeri (PPh, PPN, PBB, BPHTB, Cukai dan Pajak Lainnya) serta Pajak Perdagangan Internasional (Bea Masuk dan Pajak Ekspor).

Besarnya kontribusi sektor perpajakan terhadap penerimaan negara sangat dominan, apabila dibandingkan dengan penerimaan bukan pajak yang berasal dari: Penerimaan Sumber Daya Alam, Bagian Laba BUMN, Penerimaan Bukan Pajak Lainnya, dan Pendapatan Badan Layanan Umum. Dalam kurun waktu yang sama, penerimaan negara yang bukan pajak pada tahun 2010 sebesar Rp. 268.942 milyar, tahun 2011 sebesar Rp. 331.472 milyar, tahun 2012 sebesar Rp. 351.800 milyar, tahun 2013 sebesar Rp. 349.200 milyar dan tahun 2014 sebesar Rp. 350.900 milyar.

Mengingat begitu dominannya peranan sektor perpajakan dalam pembiayaan pembangunan nasional sebagaimana diuraikan di atas, Penulis memberikan apresiasi atas adanya Surat Direktur Pemeriksaan dan Penagihan Direktorat Jenderal Pajak (Surat Direktur Pemeriksaan dan Penagihan Direktorat Jenderal Pajak No. S-668/PJ.04/2014 tanggal 22 April 2014), yang meminta penulis untuk memaparkan. "Kerjasama dalam Rangka Optimalisasi Penerimaan Pajak dari Bidang Pajak" Pemeriksaan di bidang perpajakan tidak hanya untuk menentukan sanksi terhadap pelanggarnya, namun yang tidak kalah pentingnya agar pemeriksaan tersebut meningkatkan rasio kepatuhan (tax compliance ratio) WP. Pada titik inilah sesungguhnya kerjasama dan koordinasi dengan aparatur penegak hukum memiliki nilai strategis, sehingga penegakan hukum di bidang perpajakan senantiasa berbanding lurus dan senantiasa memberikan kontribusi positif terhadap aspek penerimaan negara.

\section{B. UU KUP Sebagai Administrative Penal Law}

Dilihat dari konteks politik perundangundangan, sektor perpajakan sejak tahun 1983 telah melakukan langkah-langkah reformatif (law reform) yang ditandai dengan dikeluarkannya 5 (lima) paket undang-undang di bidang perpajakan. Kelima produk legislasi itu terdiri dari:

1) Undang-Undang Nomor 6 Tahun 1983 tentang Ketentuan Umum dan Tata Cara Perpajakan (UU KUP), Lembaran Negara Tahun 1983 No. 49, Tambahan Lembaran Negara No. 3262.

2) Undang-Undang Nomor 7 Tahun 1983 tentang Pajak Penghasilan (UU PPh), Lembaran Negara Tahun 1983 No. 50, TLN No. 3263.

3) Undang-Undang Nomor 8 Tahun 1983 tentang Pajak Pertambahan Nilai Barang dan Jasa dan Pajak Penjualan atas Barang Mewah (UU PPN dan PPnBM).

4) Undang-Undang Nomor 12 Tahun 1985 tentang Pajak Bumi dan Bangunan (UU PBB).

5) Undang-Undang Nomor 13 Tahun 1985 tentang Bea Materai (UU BM), Lembaran Negara 1985 No. 69, TLN No. 3313).

Salah satu hal yang melatarbelakangi tax reform melalui pemberlakuan 5 (lima) paket undang-undang perpajakan itu, sebagai akibat menurunnya harga minyak bumi di pasaran dunia yang berdampak pada berkurangnya penerimaan negara (Miyasto, 1997: 7). Meskipun paket undang-undang di bidang perpajakan telah disepakati pemerintah dan Dewan Perwakilan Rakyat pada tahun 1983, namun sesungguhnya eksistensi tax reform baru dimulai pada 1 Januari 1984. Demikian pula dengan UU PBB melalui ketentuan Pasal 1 UU No. 8 Tahun 1984 dan UU PPN melalui ketentuan Pasal 31 UU No. 12 Tahun 1985 , telah menangguhkan pemberlakuannya sampai tanggal 1 Januari 1986.

Undang-Undang No. 6 Tahun 1983 tentang Ketentuan Umum dan Tata Cara Perpajakan (UU KUP 1983), merupakan produk legislasi yang menjadi dasar dan pedoman terhadap berbagai peraturan perundang-undangan di bidang-bidang pajak lainnya. UU KUP 1983 telah beberapakali dirubah dan disempurnakan melalui UndangUndang No. 9 Tahun 1994, Undang-Undang No. 16 Tahun 2000, Undang-Undang No. 28 Tahun 
2007 dan terakhir disempurnakan melalui UndangUndang No. 16 Tahun 2009.

Salah satu bagian esensial dari UU KUP sebagai hukum positif di bidang perpajakan, yaitu dimuatnya ketentuan pidana dalam suatu bab tersendiri. Adanya ketentuan pidana dalam perundang-undangan di bidang administrasi, termasuk dalam UU KUP, dinamakan administrative penal law (Verwaltungs Strafrecht) yang termasuk dalam kerangka public welfare offenses (Ordnungswidrigkeiten) (Muladi, 1990: 148-149). Pendek kata, istilah administrative penal law dapat diartikan sebagai seluruh produk legislasi berupa perundang-undangan dalam lingkup administrasi yang memiliki sanksi pidana (Indriyanto Seno Adji, 2007: 45).

Keberadaan ketentuan pidana di dalam penegakan hukum administrasi sebagaimana dikemukakan Logeman, dimaksudkan untuk memberikan kaidah-kaidah yang membimbing turut serta pemerintah dalam pergaulan sosial ekonomi, yaitu kaidah-kaidah yang oleh pemerintah sendiri diberi sanksi dalam hal terjadinya pelanggaran (T.H. Ranidajita: 21). Padahal konsep hukum pidana menurut H.L.A Hart (H.L.A. Hart, 2011: 31), merupakan sesuatu yang seharusnya dipatuhi atau tidak dipatuhi dan apa yang diwajibkan oleh aturannya dikatakan sebagai "tugas" atau "kewajiban". Fungsi sosial yang ditunjukkan oleh undang-undang pidana, yakni mengatur dan mengidentifikasikan jenis-jenis aturan tertentu yang harus dihindari.

Sebagai sebuah administrative penal law, maka di dalam UU KUP telah dinegasikan bahwa sanksi pidana ditempatkan sebagai upaya terakhir (the last resort) setelah dilakukannya tindakantindakan administrasi. Penempatan sanksi pidana sebagai ultimum remmedium, sangat jelas terlihat dari spirit, batang tubuh maupun penjelasan pasalpasal yang dimuat dalam UU KUP.

Ketentuan Pasal 13A UU KUP secara tegas menyebutkan bahwa:

"Wajib pajak karena kealpaannya tidak menyampaikan Surat Pemberitahuan atau menyampaikan Surat Pemberitahuan, tetapi isinya tidak benar atau tidak lengkap, atau melampirkan keterangan yang isinya tidak benar sehingga dapat menimbulkan kerugian pada pendapatan negara, tidak dikenai sanksi pidana apabila kealpaan tersebut pertama kali dilakukan oleh Wajib Pajak dan Wajib Pajak tersebut wajib melunasi kekurangan pembayaran jumlah pajak yang terutang beserta sanksi administrasi berupa kenaikan sebesar 200\% (dua ratus persen) dari jumlah pajak yang kurang dibayar yang ditetapkan melalui penerbitan Surat Ketetapan Pajak Kurang Bayar."

Setidaknya ada 2 (dua) poin penting dari ketentuan Pasal 13A UU KUP, yang dapat mengeliminir ataupun menunda dikenakannya sanksi pidana terhadap Wajib Pajak yang melakukan pelanggaran di bidang perpajakan, yaitu:

1) Apabila pelanggaran di bidang perpajakan itu baru pertama kali dilakukan wajib pajak;

2) Apabila Wajib Pajak melunasi kekurangan utang pajak berikut sanksi administrasi sebesar dua kali lipat dari kekurangan utang pajaknya.

Tentu saja kedua syarat tersebut menarik untuk dikaji lebih lanjut, mengingat Pasal 38 UU KUP yang nota bene memuat rumusan delik yang sama unsur-unsurnya dengan Pasal 13 A UU KUP, justru ditempatkan dalam Bab VIII tentang Ketentuan Pidana. Tetapi lagi-lagi kedua pasal dan penjelasannya itu menegaskan, bahwa "pengenaan sanksi pidana merupakan upaya terakhir untuk meningkatkan kepatuhan wajib pajak".

Persoalan menarik lainnya terkait dengan unsur kealpaan (culpa) dalam Pasal 13A dan Pasal 38 UU KUP, sebagaimana halnya juga kesengajaan (opzet) yang merupakan bentuk kesalahan dan unsur subyektif dapat dipidananya pelaku. Akan tetapi kedua pasal itu tetap menggariskan, bahwa pemidaan terhadap wajib pajak yang telah melakukan pelanggaran untuk kedua kalinya. Lebih lanjut dijelaskan dalam Pasal 38 UU KUP bahwa sanksi administrasi terhadap wajib pajak berupa penerbitan Surat Ketetapan Pajak atau Surat Tagihan Pajak.

Penempatan hukum pidana sebagai ultimum remmedium dalam UU KUP, tercermin pula dari ketentuan Pasal 44B. Atas dasar kepentingan penerimaan negara, Menteri Keuangan dapat meminta Jaksa Agung untuk menghentikan penyidikan tindak pidana di Bidang Perpajakan. Adapun syarat usulan penghentian penyidikan itu, apabila wajib pajak mau melunasi kekurangan utang pajaknya berikut sanksi administrasi sebesar $400 \%$ atau 4 (empat) kali lipat dari pajak yang kurang bayar itu.

Tentu saja karakteristik UU KUP sebagai administrative penal law, perlu dipahami oleh mereka yang diberikan kewenangan oleh undangundang untuk melakukan pemeriksaan di bidang perpajakan. Hal itu dikarenakan serangkaian pemeriksaan yang dilakukan terhadap wajib pajak, sejatinya haruslah dimaknai sebagai upaya untuk meningkatkan kepatuhan dalam memenuhi kewajiban perpajakannya. Mengingat penerimaan 
negara merupakan bagian esensial dari UU KUP, maka pengenaan sanksi pidana di bidang perpajakan merupakan upaya terakhir setelah dilakukan berbagai upaya dan pendekatan yang bersifat persuasif dan preemtif.

\section{B. Pemeriksaan di Bidang Perpajakan}

Institusi yang diberikan kewenangan dan mempunyai otoritas di bidang perpajakan di Indonesia dilakukan oleh Direktorat Jenderal Pajak (Ditjen Pajak), yang berada di bawah Kementerian Keuangan RI. Otoritas Ditjen Pajak tidak hanya menyangkut pada fungsi pemungutan atau penagihan pajak (the collection function), melainkan juga dapat melakukan pemeriksaan atau verifikasi terhadap Wajib Pajak (the audit function).

Menurut ketentuan Pasal 1 butir 25 UU KUP, pemeriksaan di bidang perpajakan merupakan serangkaian kegiatan menghimpun dan mengolah data, keterangan, dan atau bukti yang dilaksanakan secara obyektif dan profesional berdasarkan suatu standar pemeriksaan. Ada 2 (dua) maksud dari pelaksanaan pemeriksaan di bidang perpajakan.

Pertama, untuk menguji kepatuhan pemenuhan kewajiban perpajakan. Pemeriksaan pajak yang dimaksudkan untuk menguji kepatuhan, dapat dilakukan oleh petugas pemeriksa terhadap wajib pajak dalam hal (Pasal 3 ayat (3) Peraturan Menteri Keuangan No. 199/PMK.03/2007):

a. menyampaikan SPT yang menyatakan lebih bayar, termasuk yang telah diberikan pengembalian pendahuluan kelebihan pajak;

b. menyampaikan SPT yang menyatakan rugi;

c. tidak menyampaikan atau menyampaikan SPT tetapi melampaui jangka waktu yang telah ditetapkan;

d. melakukan penggabungan, peleburan, pemekaran, likuidasi, pembubaran, atau akan meninggalkan Indonesia untuk selamalamanya;

e. menyampaikan SPT yang memenuhi kriteria seleksi berdasarkan hasil analisis risiko (risk based selection) mengindikasikan adanya kewajiban Wajib Pajak yang tidak dipenuhi sesuai ketentuan peraturan perundangundangan.

Kedua, untuk tujuan lain dalam rangka melaksanakan ketentuan peraturan perundangundangan. Pemeriksaan untuk melaksanakan ketentuan peraturan perundang-undangan, dilakukan oleh pemeriksa dalam hal (Pasal 30 ayat (2) Peraturan Menteri Keuangan Nomor 199/ PMK.03/2007.):

8 Yustisia. Vol.5 No.1 Januari - April 2016 a. Pemberian NPWP secara jabatan;

b. Penghapusan NPWP;

c. Pengukuhan atau pencabutan pengukuhan PKP;

d. Wajib Pajak mengajukan keberatan;

e. Pengumpulan bahan guna penyusunan Norma Perhitungan Penghasilan Neto;

f. Pencocokan data dan/atau alat keterangan;

g. Penentuan Wajib Pajak berlokasi di daerah terpencil;

h. Penentuan satu atau lebih tempat terutang PPN;

i. Pemeriksaan dalam rangka penagihan pajak;

j. Penentuan saat produksi dimulai atau memperpanjang jangka waktu kompensasi kerugian sehubungan dengan pemberian fasilitas perpajakan; dan/atau;

k. Memenuhi permintaan dari negara mitra perjanjian penghindaran pajak berganda.

Pelaksanaan pemeriksaan untuk menguji kepatuhan wajib pajak maupun untuk tujuan lain, dapat dilakukan melalui pemeriksaan kantor maupun pemeriksaan lapangan.

Pemeriksaan kantor dilaksanakan terhadap wajib pajak di Kantor Dirjen Pajak, yang meliputi satu jenis pajak tertentu pada tahun berjalan atau tahun-tahun sebelumnya. Jenis pemeriksaan ini dapat dilaksanakan melalui Pemeriksaan Sederhana Kantor (PSK) maupun melalui Pemeriksaan dengan Korespondensi (PdK). PSK dilakukan setelah memanggil wajib pajak untuk datang ke kantor Dirjen Pajak dengan membawa buku-buku, catatan-catatan dan dokumendokumen perpajakan, sedangkan PdK dilakukan dengan cara surat menyurat secara tertulis antara pemeriksa dengan wajib pajak sehingga tidak ada kontak langsung antara keduanya.

Pelaksanaan pemeriksaan kantor oleh Tim Pemeriksa Pajak berdasarkan Surat Perintah Pemeriksaan Pajak (SPPP), baik untuk satu atau beberapa masa pajak dalam suatu tahun pajak ataupun untuk satu tahun pajak terhadap satu wajib pajak. Di samping melakukan pemeriksaan terhadap buku-buku, catatan ataupun dokumen perpajakan, tim pemeriksa dapat meminta penjelasan terhadap wajib pajak sehubungan dengan data-data perpajakan yang telah diserahkannya. Apabila wajib pajak telah dipanggil secara patut sebanyak 2 (dua) kali, namun tidak mengindahkannya tanpa alasan yang jelas maka Kepala KPP dapat menerbitkan Surat Ketetapan Pajak (SKP) secara jabatan sesuai dengan norma perhitungan penghasilan neto atau cara lain yang diatur peraturan perundangan-undangan yang berlaku.

Penyamaan Persepsi dan Kerjasama... 
Setelah selesai pemeriksaan kantor, selanjutnya Tim Pemeriksa memberitahukan hasil pemeriksaannya dalam bentuk Surat Pemberitahuan Hasil Pemeriksaan (SPHP) berikut lampirannya kepada wajib pajak untuk mendapatkan tanggapannya. Wajib pajak yang menyetujui atas seluruh hasil pemeriksaan, kemudian menandatangani Lembar Pernyataan Persetujuan Hasil Pemeriksaan dan Berita Acara Persetujuan Hasil Pemeriksaan dan menyerahkannya kepada Kepala Unit Pelaksana Pemeriksaan Pajak (UPPP). Akan tetapi apabila wajib pajak tidak setuju atas sebagian atau seluruh hasil pemeriksaan, maka wajib pajak menyampaikannya kepada Kepala UPPP dengan dilampiri bukti-bukti pendukung sanggahan serta penjelasannya. Pemeriksaan kantor berakhir setelah dilakukan hasil pembahasan akhir dengan wajib pajak, yang dituangkan dalam Berita Acara Hasil Pemeriksaan beserta lampirannya berupa ikhtisar pembahasan akhir sebagai bagian yang tidak terpisahkan dari Laporan Pemeriksaan Pajak (LHP).

Pemeriksaan lapangan dapat dilakukan apabila perhitungan jumlah terutang tidak dapat dilakukan pada saat pemeriksaan sederhana kantor, karena data yang tidak lengkap atau terbatasnya data/keterangan yang diperoleh pemeriksa. Pelaksanaan pemeriksaan lapangan dilakukan di tempat kedudukan, tempat usaha, tempat tinggal wajib pajak ataupun tempat lainnya yang ditentukan oleh Dirjen Pajak.

Suatu hal penting dalam rangka pelaksanaan pemeriksaan pajak, yaitu Laporan Hasil Pemeriksaan yang diantaranya memuat ruang lingkup pemeriksaan, ikhtisar hasil pemeriksaan, penghitungan pajak terutang serta simpulan pemeriksaan. Dikarenakan LHP tersebut digunakan sebagai dasar penerbitan Surat Ketetapan Pajak (SKP) dan/atau Surat Tagihan Pajak, sehingga Wajib Pajak berhak untuk menerima Surat Pemberitahuan Hasil Pemeriksaan. Sepanjang tidak ditemukan adanya indikasi tindak pidana di bidang perpajakan, maka Dirjen Pajak akan mengenakan sanksi administrasi berupa bunga, kenaikan dan denda.

Apabila ditemukan adanya indikasi tindak pidana di bidang perpajakan, maka akan dilanjutkan dengan pemeriksaan bukti permulaan (Pasal 1 butir 26 UU KUP 2007). Oleh karenanya, pemeriksaan bukti permulaan dimaksudkan untuk mendapatkan bukti permulaan tentang adanya dugaan telah terjadi tindak pidana di bidang perpajakan. Di samping adanya indikasi tindak pidana di bidang perpajakan, pemeriksaan bukti permulaan dapat dilakukan dalam hal:

(1) Wajib pajak tidak meminjamkan buku, catatan atau dokumen, sehingga besarnya penghasilan kena pajak tidak dapat dihitung;

(2) Wajib pajak menolak untuk dilakukan pemeriksaan, tidak memenuhi panggilan pada saat pemeriksaan kantor ataupun menolak membantu kelancaran pemeriksaan. Apabila ditemukan adanya indikasi tindak pidana di bidang perpajakan, maka pemeriksaan bukti permulaan dapat dilanjutkan dengan kegiatan penyidikan dan penuntutan di Pengadilan Negeri.

Pemeriksaan bukti permulaan dapat dihentikan dan tidak dilanjutkan dengan kegiatan penyidikan, apabila tidak ditemukan adanya indikasi tindak pidana di bidang perpajakan. Pemeriksaan bukti permulaan juga tidak akan dilanjutkan, seandainya wajib pajak dengan kemauannya sendiri menyampaikan ketidakbenaran dalam menyampaikan SPT/SPM dan melunasi pajak terutang disertai dengan sanksi administrasinya. Dalam penghentian pemeriksaan bukti permulaan, maka dibuat laporan hasil pemeriksaan sumir yang menyebutkan bahwa:

(1) penyelesaiannya dilakukan dengan penerbitan SKP;

(2) wajib pajak mengungkapkan sendiri ketidakbenaran SPTnya dengan membayar hutang pajak dan sanksi administrasi; atau

(3) penghentian penyidikan karena wajib pajak telah membayar hutang pajak dan sanksi administasi sebesar $400 \%$ sebagaimana dimaksud Pasal 44B UU KUP.

Bertolak dari uraian di atas, menggambarkan bahwa kegiatan pemeriksaan merupakan prasyarat mutlak untuk dapat diterapkannya sanksi di bidang perpajakan terhadap wajib pajak. Secara ringkas, mekanisme pemeriksaan untuk menguji kepatuhan wajib pajak dapat digambarkan dalam Bagan 1 berikut. 


\section{Bagan 1}

\section{Mekanisme Pemeriksaan Untuk Menguji Kepatuhan Wajib Pajak}

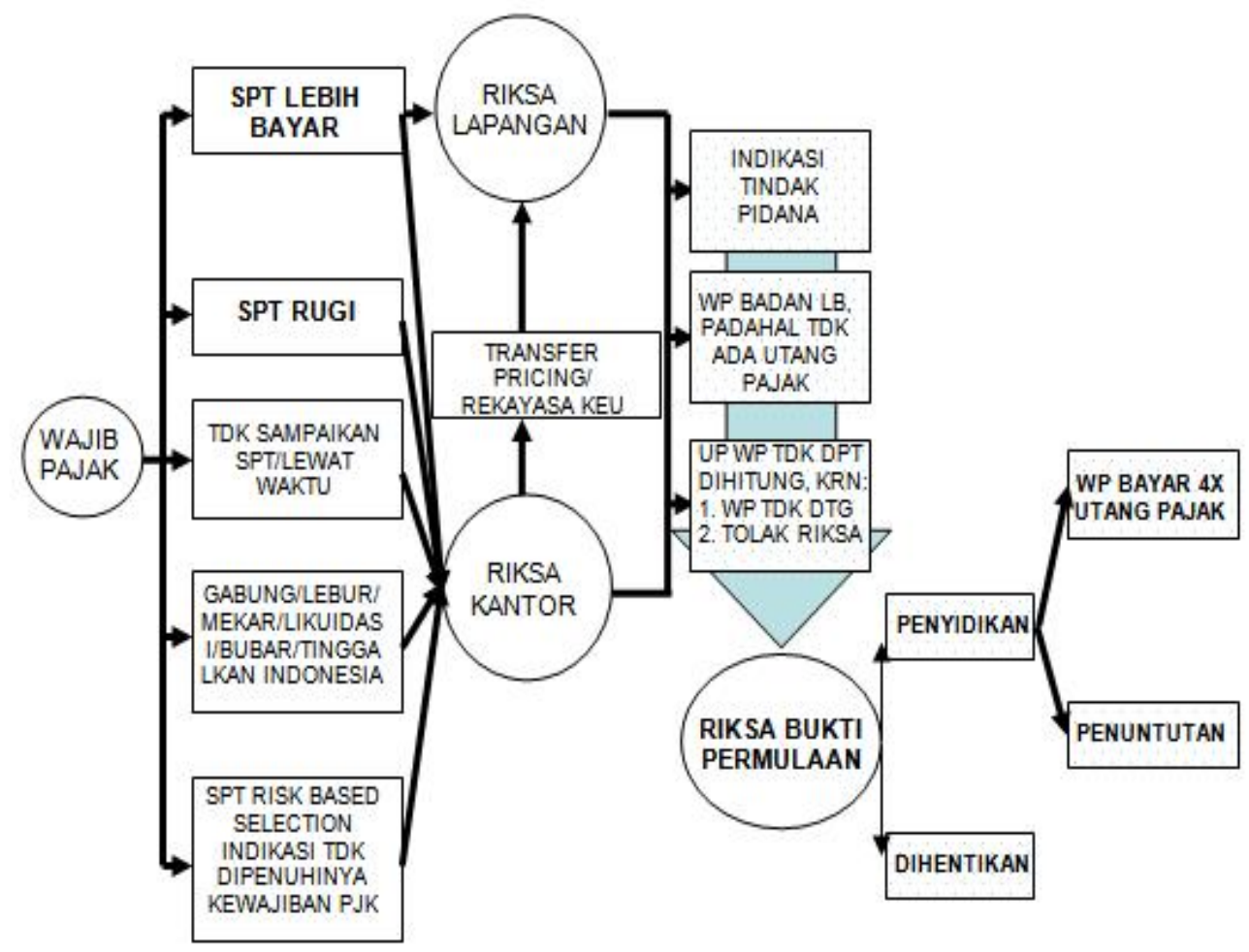

\section{Beberapa Persoalan Krusial Dalam Pemeriksaan di Bidang Perpajakan}

Mencermati peraturan perundang-undangan dan berbagai praktik penegakan hukum di bidang perpajakan saat ini, Penulis masih melihat belum korelasi positif antara pemeriksaan di bidang perpajakan dengan peningkatan penerimaan negara dari wajib pajak. Setidaknya terdapat 2 (dua) gambaran yang memperkuat argumentasi tersebut, baik dari peraturan perundang-undangan terkait tata cara dan mekanisme penerapan sanksi di bidang perpajakan maupun praktik penerapan sanksi terhadap wajib pajak yang dilakukan oleh Ditjen Pajak.

Dalam kaitan dengan tata cara dan mekanisme penerapan sanksi di bidang perpajakan, Menteri Keuangan maupun Dirjen Pajak telah mengeluarkan peraturan, keputusan maupun surat edaran serta berbagai peraturan tertulis lainnya. Menurut penulis, berbagai produk hukum tertulis tersebut masih terfokus pada 4 (empat) hal, yaitu: Tata Cara Pemeriksaan, Tata Cara Pemeriksaan Bukti Permulaan, Standard Operating Procedures (SOP), Tata Cara Penanganan Informasi, Data, Laporan dan Pengaduan (IDLP) (Asep N. Mulyana, 2012: 258-259 ).
Keempat rumpun pengaturan itu, nampaknya berbagai produk hukum yang dikeluarkan oleh Menteri Keuangan maupun Dirjen Pajak tidak ada yang secara khusus mengatur mengenai parameter penerapan sanksi oleh Ditjen Pajak terhadap indikasi dugaan penyimpangan dan pelanggaran yang dilakukan oleh Wajib Pajak. Substansi dari Standard Operating Procedures (SOP) yang diatur melalui Surat Edaran Dirjen Pajak No. SE-4/PJ/2009 misalnya, hanya memuat tentang tata kerja dan tugas pokok para pejabat Ditjen Pajak, baik di KPP, Kanwil DJP maupun di Kantor Pusat DJP. Begitu pula halnya dengan substansi Peraturan Menteri Keuangan dan Peraturan Dirjen Pajak terkait Tata Cara Pemeriksaan Pajak, juga tidak mengatur secara jelas mengenai parameter penerapan sanksi di bidang perpajakan terhadap Wajib Pajak.

Hal yang sama terkait pula pengaturan mengenai Tata Cara Pemeriksaan Bukti Permulaan dan petunjuk pelaksanaannya, hanya mengatur mengenai prosedur formal pelaksanaan pemeriksaan bukti permulaan mulai dari usulan, instruksi, surat perintah, waktu pelaksanaan, tata cara perolehan barang bukti maupun permintaan keterangan, tetapi tidak ada satu ketentuan yang

Penyamaan Persepsi dan Kerjasama... 
mengatur mengenai klasifikasi pembedaan secara jelas antara pelanggaran yang bersifat administrasi dengan tindak pidana di bidang perpajakan yang dilakukan oleh Wajib Pajak. Bahkan di dalam Penjelasan tentang Bukti Permulaan Adanya Tindak Pidana di Bidang Perpajakan, hanya menentukan 7 (tujuh) jenis perbuatan yang dapat dikelompokkan sebagai bukti permulaan adanya tindak pidana di bidang perpajakan, yaitu:

a. Wajib pajak dengan sengaja tidak mendaftarkan diri.

b. Wajib Pajak dengan sengaja menyalahgunakan atau menggunakan tanpa hak NPWP.

c. Wajib Pajak tidak menyampaikan SPT.

d. Wajib Pajak dengan sengaja menyampaikan SPT yang isinya tidak benar atau tidak lengkap atau melampirkan keterangan yang tidak benar.

e. Wajib Pajak dengan sengaja memperlihatkan pembukuan, catatan atau dokumen lain yang palsu atau dipalsukan seolah-olah benar.

f. Wajib pajak dengan sengaja tidak bersedia memperlihatkan atau meminjamkan pembukuan, catatan atau dokumen lainnya.

g. Wajib pajak dengan sengaja tidak menyetorkan pajak yang telah dipotong atau dipungut.

Meskipun di dalam Peraturan Dirjen Pajak telah ditentukan bahwa Laporan Hasil Pemeriksaan Bukti Permulaan, setidaknya menggambarkan mengenai: (a) perhitungan besarnya kerugian pada pendapatan negara; (b) modus operandi; dan(c) pasal-pasal yang dilanggar. Pada kenyataannya, Peraturan Dirjen Pajak itu tidak juga mengatur secara tegas pembedaan kualifikasi antara pelanggaran administrasi dengan tindak pidana di bidang perpajakan. Akibatnya terdapat kebijakan Dirjen Pajak yang bersifat dualisme dan terkesan diskriminatif, ketika menemukan adanya dugaan pelanggaran terhadap ketentuan di dalam UU KUP sehingga juga akan menerapkan sanksi yang berbeda terhadap kasus-kasus yang sama.

Terkait dengan pelaksanaan pemeriksaan pajak, Dirjen Pajak telah mengeluarkan Surat Edaran No. SE-04/PJ.04/2008 tanggal 23 Juni 2008 tentang Pelaksanaan Pemeriksaan pada KPP Pratama di seluruh Indonesia selain KPP Pratama di Kanwil DJP Jakarta Pusat. Akan tetapi surat edaran tersebut hanya berkaitan dengan tenaga pemeriksa pajak, dan tidak mengatur tentang mekanisme pelaksanaan pemeriksaan pajak. Dalam praktiknya, penentuan suatu pelanggaran ataupun penyimpangan yang dilakukan oleh wajib pajak untuk dapat dikualifikasikan sebagai tindak pidana di bidang perpajakan hanyalah berdasarkan kebijakan dari:
1) Direktur Intelijen dan Penyidikan, khususnya terhadap usulan pemeriksaan bukti permulaan yang diajukan oleh Sub Direktorat Intelijen Perpajakan, Sub Direktorat Rekayasa Keuangan dan Sub Direktorat Pemeriksaan Bukti Permulaan;

2) Kepala Kantor Wilayah Direktorat Jendral Pajak, yaitu terhadap usulan pemeriksaan bukti permulaan yang diajukan oleh Kepala Bagian Pemeriksaan, Penyidikan dan Penagihan Pajak;

3) Direktur Jenderal Pajak melalui Direktur Intelijen dan Penyidikan, khususnya terhadap usul pemeriksaan bukti permulaan yang dilakukan melalui pemeriksaan ulang.

Persoalan yang senada, juga terkait dengan Peraturan Dirjen Pajak tentang Tata Cara Pelaksanaan Pengembangan dan Analisis Informasi, Data, Laporan dan Pengaduan (IDLP) (Peraturan Dirjen Pajak Nomor Per-38/PJ/2010). Meskipun dalam Peraturan Dirjen Pajak itu telah 3 (tiga) kelompok kualitas pengembangan analisis IDLP berikut tindak lanjutnya, namun dalam realitasnya tidak mampu mengliminir adanya standar ganda dalam menindaklanjuti dugaan pelanggaran di bidang perpajakan. Bahkan menurut pengakuan sebagian para pemeriksa di lapangan, penetapan kelompok kualitas melalui sistem skoring yang dianut Peraturan Dirjen Pajak itu cenderung tidak realistis dan membingungkan dalam pelaksanaannya.

Standar ganda yang diterapkan Ditjen Pajak dalam menindaklanjuti pelanggaran peraturan perundang-undangan di bidang perpajakan, terlihat dalam penanganan perkara pelanggaran Pasal 39 UU KUP. Lebih memprihatinkan lagi, kerapkali ketentuan Pasal 39 UU KUP telah digunakan sebagai "pasal karet" yang bersifat kenyal dan dapat diterapkan sesuai dengan selera aparat, sebagaimana halnya Pasal 335 KUHP tentang Perbuatan Tidak Menyenangkan .

Di satu sisi, aparat Ditjen Pajak cenderung untuk menerbitkan SKP meskipun telah dilakukan penyimpangan dan pelanggaran berulangkali oleh wajib pajak. Pada sisi lain, ada juga aparat Ditjen Pajak yang langsung melakukan pemeriksaan Bukti Permulaan dan ditindaklanjuti dengan kegiatan penyidikan, meskipun pelanggaran yang dilakukan oleh wajib pajak baru untuk pertama kalinya.

Tidak adanya kejelasan dan ketegasan dalam menentukan parameter penerapan sanksi, dapat menimbulkan kerawanan-kerawanan dalam pemeriksaan di bidang perpajakan. Tentu saja kerawanan itu tidak hanya membuka peluang terjadinya berbagai penyimpangan, tetapi juga 
dapat menjadi kontraproduktif terhadap kepatuhan wajib pajak itu sendiri yang pada gilirannya dapat berimplikasi negatif terhadap penerimaan negara.

\section{E. Penyamaan Persepsi dan Kerjasama Antar Penegak Hukum Dalam Rangka Optimalisasi Penerimaan Negara Dari Sektor Pajak}

Memahami hakikat pajak dan berbagai persoalan sebagaimana yang telah diuraikan di atas, nampaknya pendekatan represif bukanlah satu-satunya formula yang tepat dalam rangka meningkatkan penerimaan negara dari sektor perpajakan. Namun membiarkan banyaknya peluang dan "loop hole" yang dapat dimanfaatkan oleh oknum-oknum untuk melakukan penyimpangan, bukan juga merupakan pilihan bijak dalam rangka pemeriksaan dan penegakan hukum di bidang perpajakan.

Atas dasar konstruksi berfikir seperti itulah, maka yang seharusnya diupayakan dan dikedepankan adanya keterpaduan antara pemeriksaan pajak dan penegakan hukum di satu pihak dengan optimalisasi penerimaan negara pada pihak lainnya. Ini berarti bahwa antara proses pemeriksaan dan penegakan hukum di bidang perpajakan, sejatinya dapat membawa pengaruh yang signifikan terhadap peningkatan kepatuhan wajib pajak dalam rangka memenuhi kewajiban perpajakannya.

Menurut hemat penulis, setidaknya ada 2 (dua) hal penting yang seharusnya dikedepankan dalam rangka kerjasama dan koordinasi antara Ditjen Pajak dengan Penegak Hukum dalam rangka menciptakan adanya sinergitas antara pemeriksaan dan penegakan hukum dengan peningkatan penerimaan negara. Pertama, diperlukan adanya pemetaan (road map) terhadap karakteristik pelanggaran dan penyimpangan di bidang perpajakan.

Pemetaan terhadap karakteristik penyimpangan tersebut menjadi langkah awal untuk dapat menentukan tindakan (treatment) yang paling tepat, ketika terjadinya pelanggaran dan penyimpangan di bidang perpajakan. Diharapkan melalui adanya pemetaan ini akan terdapat kesamaan pola pikir, pemahaman dan kesamaan tindakan dalam menindaklanjuti adanya dugaan penyimpangan di bidang perpajakan, apakah melalui tindakan administrasi ataukah melalui penegakan hukum pidana.

Penulis menganggap pemataan terhadap karakteristik pelanggaran di bidang perpajakan merupakan bagian terpenting, mengingat saat ini masih terdapat perbedaan persepsi di antara aparat penegak hukum dalam menindaklanjuti dugaan terjadinya pelanggaran tersebut. Perbedaan persepsi antar aparat penegak hukum biasanya terkait klasifikasi pelanggaran administrasi, tindak pidana di bidang perpajakan, maupun korupsi di bidang perpajakan. Untuk mengeliminir hal itulah, maka secara internal Bidang Pidana Khusus Kejaksaan Agung telah membuat Blue Print Modus Operandi Tindak Pidana Korupsi di Indonesia (Anonim, 2013: 46-57). Di dalam Blue Print itu, antara lain telah digambarkan mengenai kemungkinan berikut pemetaan inti masalah terjadinya tindak pidana korupsi di bidang perpajakan.

Melalui pemahaman yang benar dan komprehensif terhadap karakteristik pelanggaran di bidang perpajakan, maka akan secara jelas pula menentukan institusi mana yang berwenang menangani dan menetapkan jenis sanksinya. Sebagaimana yang dikemukakan Buys dan Thorbecke (Rochmat Soemitro, 1991: 11) persoalan objectum litis (pokok masalah) dan fundamentum petendi menjadi hal penting untuk menentukan institusi mana yang menanganinya serta sanksi yang paling tepat terhadap pelanggarnya.

Kedua, diperlukan adanya integrasi antara penyelesaian utang pokok pajak dengan proses peradilan pidana. Selama ini antara proses peradilan pidana dengan penyelesaian utang pokok pajak, merupakan dua hal yang terpisah dan terkadang berhadap-hadapan.

Ketika seorang wajib pajak diproses melalui mekanisme peradilan pidana dan dikenakan sanksi pidana berikut denda, maka pada saat itu pula aparat Ditjen Pajak menerbitkan SKP sebagai dasar penagihan utang pajaknya. Padahal salah satu dasar dalam menentukan unsur kerugian pada pendapatan negara, sesungguhnya merupakan utang pajak hasil perhitungan dan pemeriksaan pajak. Akibatnya penerbitan SKP yang dilakukan setelah proses peradilan pidana, justru menimbulkan banyaknya "utang pajak menggantung" dan "piutang pajak yang tidak bertuan".

\section{F. Simpulan}

Demikian beberapa pokok pikiran yang dapat penulis paparkan dalam Rapat Koordinasi Nasional Pemeriksaan Pajak Tahun 2014, semoga dapat menjadi bahan kajian lebih lanjut untuk menyamakan persepsi dan kesatuan gerak langkah dalam rangka pemeriksaan di bidang perpajakan serta sebagai momentum dan cikal bakal, khususnya dalam merumuskan pedoman penerapan sanksi pidana di bidang perpajakan 
(standard guidelines on penal taxation).

Kesamaan persepsi dan gerak langkah itu, sejatinya ditempatkan pada kepentingan bangsa yang lebih besar. Dalam konteks perpajakan, tentu saja tujuan utamanya agar terdapat sinergitas antara penegakan hukum di bidang perpajakan dengan optimalisasi penerimaan negara.

\section{Daftar Pustaka}

Anonim. 2013. Pemetaan (Blue Print) Modus Operandi Tindak Pidana Korupsi di Indonesia. Jakarta: Jaksa Agung Muda Tindak Pidana Khusus Kejaksaan Republik Indonesia.

Asep N. Mulyana. 2012. Konsep Sanksi dalam Tindak Pidana Perpajakan Dihubungkan dengan Upaya Peningkatan Penerimaan Negara. Disertasi. Bandung: Universitas Padjadjaran.

Bagir Manan, "Politik Perundang-Undangan dalam Rangka Mengantisipasi Liberalisasi Perekonomian", Makalah, Bandar Lampung: Seminar Nasional tentang Sosialisasi Undang-Undang No. 1 Tahun 1995 tentang Perseroan Terbatas, FH-Universitas Lampung, 9 Maret 1996.

H.L.A. Hart. 2011. Konsep Hukum, Alih Bahasa Mohammad Nashihan dkk, Jakarta: Cintya Press.

Indriyanto Seno Adji. "Kendala Administrative Penal Law Sebagai Tindak Pidana Korupsi \& Pencucian Uang", Makalah. Seminar Nasional Penanganan Tindak Pidana Kehutanan \& Tindak Pidana Pencucian Uang dalam Perspektif Tindak Pidana Korupsi. Jakarta: Sasana Pradana Kejaksaan Agung RI, 16 Juli 2007.

Lilik Mulyadi. 2007. Tindak Pidana Korupsi di Indonesia; Normatif. Teoritis. Praktik dan Masalahnya. Bandung: Alumni. Cetakan Pertama.

Miyasto. 1997. Sistem Perpajakan Nasional dalam Era Globalisasi; Pidato Pengukuhan Guru Besar dalam IImu Ekonomi. Semarang: Fakultas Ekonomi Universitas Diponegoro.

Muladi. 1990. Proyeksi Hukum Pidana Materiil Indonesia di Masa Datang, Naskah Pidato Pengukuhan Guru Besar dalam Ilmu Hukum pada Fakultas Hukum Universitas Diponegoro. Semarang.

Rochmat Soemitro. 1991. Peradilan Administrasi dalam Hukum Pajak di Indonesia. Bandung: Eresco. Cetakan Kelima.

T.H. Ranidajita,"Eksistensi Sanksi Pidana Dalam Hukum Administrasi Negara Khususnya Hukum Pajak di Indonesia" dalam Masalah-Masalah Hukum, Semarang: FH-UNDIP No. 4 Tahun 1994.

Internet:

Badan Pusat Statistik, www.bps.go.id 